\title{
MARX, ENGELS E OS ESCRITORES ROMÂNTICOS
}

1. MARX, ENGLES. Sur la litterature et l'art. FREVILLE, Jean (org). Paris: ESI, 1936. inspiraçãno bastante divers de inspiraçăo bastante diversa, foi publicada recentemente: Marx and Engels on Literature and Art. Saint Louis a. Morawski (org). Saint Louis and Milwaukee: Telos Press, 1973.

\section{Robert Sayre* Michael Löwy** \\ Maria Juliana Gambogi} Teixeira (trad.)***

\section{MARX E ENGELS CONTRA O ROMANTISMO?}

Há toda uma literatura, em particular de inspiração stalinista, que tende a apresentar os autores do Manifesto Comunista como adversários do Romantismo, rejeitando em bloco essa corrente cultural, entendida como "reacionária”. Um exemplo típico é o livro publicado em 1936 por Jean Fréville pela Editions Sociales Internationales, o qual representa, ainda hoje, a única coletânea em língua francesa dos textos de Marx e Engels sobre literatura e arte. ${ }^{1}$ Em sua introdução, Fréville, citando com entusiasmo a definição, proposta por Stalin, dos escritores como "engenheiros d alma”, reconhece ser o Romantismo não apenas uma reação
Professor de Literaturas anglófonas na Universdade de Paris-Est Marne-la-Vallé

* Diretor de pesquisas no Centro Nacional de Pesquisa Científica - CNRS.

** juliana.gambogi22@gmail.com

Doutora, professora de língua e literatura francesa na Faculdade de Letras - UFMG.

contra a arte clássica, mas "o protesto desesperado contra o capitalismo, entoado tanto pela nobreza empobrecida quanto pela pequena burguesia radical". ${ }^{2}$ Apesar disso, o capítulo consagrado ao Romantismo nessa coletânea é intitulado, muito simplesmente, "Contra o Romantismo"! Na realidade, muitos dos textos citados - por exemplo, os de Engels sobre Carlyle - estão longe de cair numa rejeição tão simplista. Um outro capítulo, intitulado por Fréville "Os perigos do Romantismo”, não trata nem de literatura nem de arte, mas de alguns deputados conservadores da Dieta Renana. Um trecho de um artigo de Engels critica os "raivosos comedores de franceses", mas a palavra "Romantismo" não aparece
2. MARX, ENGELS. Sur la littérature et l'art. Introduction, p. 10. 
3. Ver, em particular, o nosso Révolte et mélancolie: le romantisme à contre-courant 1992, assim como o número 1992, assim como o número da revista Europe, consagrado ao "Romantisme révolutionnaire." ali. Enfim, um outro conjunto de extratos, intitulado por Fréville "O Romantismo reacionário", introduz uma carta de Marx para Engels que analisaremos a seguir, mas na qual não há menção ao termo "reacionário": o que a carta menciona é, simplesmente, a existência de duas "reações" às Luzes, a romântica e a socialista.

$\mathrm{Na}$ realidade, a posição de Marx e Engels acerca do Romantismo é bem mais cheia de nuances e, sobretudo mais dialética do que o proposto por essa versão caricatural, sem dúvida inspirada pela ideologia do progresso de origem positivista, que deixou marcas em grande parte da cultura de esquerda francesa.

\section{O QUE É O ROMANTISMO?}

Antes de abordar a questão do posicionamento de Marx e Engels acerca do Romantismo e, num segundo momento, acerca dos escritores românticos, é importante definir como o entendemos. Tomamos como ponto de referência aqui uma concepção substantiva do fenômeno romântico, oriunda de certas sugestões de Marx e Engels, sem, necessariamente, adotar sua terminologia para descrever tal ou qual autor. De acordo com essa concepção - já esboçada em outros momentos ${ }^{3}$-, o Romantismo não se limita nem a movimentos literários e artísticos, tampouco ao período do início do século XIX, frequentemente considerado como "período romântico", durante o qual se desenvolveram correntes e escolas comumente tratadas como românticas. A nosso ver, tais movimentos se inserem em uma tendência cultural muito mais vasta, inerente a uma mutação sócio-histórica fundamental e de grande alcance: a ascensão - progressivamente mundial - de uma sociedade completamente regida pelo mercado e na qual os diversos valores qualitativos encontrados em sociedades "tradicionais" precedentes serão substituídos exclusivamente pelo valor quantitativo do dinheiro.

É essa sociedade capitalista - um tipo sem precedentes que suscitará reações de protesto ou de recusa, expressos em distintos domínios culturais - a filosofia política, o direito, a história, etc, bem como a literatura e a arte -, em nome de valores qualitativos perdidos do passado. É esta revolta cultural e multifacetada - marcada pela nostalgia de alguns ideais do passado, sem, necessariamente, desejar a restauração de formações sociais de outros tempos - que constitui, a nosso ver, o Romantismo. Nascido por volta de meados do século XVIII, no mesmo momento em que o capitalismo se institui e se impõe na Inglaterra e na Europa, essa revolta perdura ainda hoje, já que, malgrado importantes transformações em suas modalidades, o sistema socioeconômico contra o qual ela se institui ainda persiste e faz sentir suas consequências de maneira cada vez mais universal.
EM TESE
BELO HORIZONTE
v. 20
N. 1
JAN.ABR. 2014 SAYRE; LÖWY; TEIXEIRA. Marx, Engels e os escritores românticos
P. $134-148$

Tradução e Edição 
Durante essa longa duração da Modernidade capitalista, claro está que nem de longe todos os intelectuais, artistas e escritores aderiram a tal concepção de Romantismo. De um lado, há os que aceitam globalmente o status quo da sociedade moderna; mas também existem alguns, em meio aos que contestam a ordem capitalista, que o fazem em nome da própria Modernidade ou de alguns dos valores hegemônicos da Modernidade - a razão, a ciência, o indivíduo. Para que possamos falar de visão ou de perspectiva romântica, é necessário que a crítica anticapitalista seja feita sob a inspiração de uma certa ideia de passado, em nome de algo encarnado por esse passado, mesmo que não se deseje sua reconstituição.

\section{MARX, ENGELS E O ROMANTISMO}

Claro está que Marx e Engels, herdeiros críticos do Iluminismo, não foram exatamente românticos no sentido dessa definição. No entanto, a crítica romântica da civilização capitalista - desenvolvida por pensadores políticos, economistas, antropólogos, socialistas - resta sendo uma fonte extremamente importante e, no geral, negligenciada, para as suas reflexões. Alguns textos-chave permitem compreender sua atitude global face à perspectiva romântica, tal como a definimos.

No Manifesto Comunista (1848), Marx e Engels se referem ao "socialismo feudal" - provavelmente uma alusão ao movimento "Jovem Inglaterra" (Disraeli, Carlyle) e a certos legitimistas franceses - como uma corrente na qual se misturam "ecos do passado" e "ameaça o futuro"; malgrado sua "total incapacidade para compreender a marcha da história moderna", esses pensadores tiveram o mérito de "atacar o coração mesmo da burguesia, através de uma crítica amarga e espiritualmente mordaz". Ainda mais importante, ao ver de Marx e Engels, é o "socialismo pequeno-burguês" de Sismondi - o mais eminente dos economistas que, no século XIX, poderia ser qualificado de romântico - cuja contribuição eles enfatizam: "Ele analisou com a maior sagacidade as contradições inerentes às relações de produção modernas. Desmascarou as falácias embelezadoras dos economistas". ${ }^{4}$

Um dos mais significativos textos de Marx sobre o Romantismo é uma passagem dos Grundrisse, os Fundamentos da Crítica da Economia Política (1857-1858): "Nos períodos anteriores da evolução, o indivíduo gozava de uma maior plenitude justamente porque, não dispondo ainda de condições materiais plenamente desenvolvidas, encara-lhes como forças e relações sociais independentes de si. Aspirar a essa plenitude do passado é tão ridículo quanto desejar a manutenção do estado atual de penúria. A concepção burguesa jamais conseguirá ir além da oposição ao ponto de vista romântico (Über den Gegensatz gegen jene romantische Ansicht ist die bürgerliche nie Herausgekommen) e, portanto, ele vai acompanhá-la, como sua legítima antítese (berechtigeter Gegensatz), até o bem aventurado fim da burguesia". Essa passagem é interessante
4. MARX, ENGELS. Manifeste du parti communiste. Paris:
Flammarion, trad. Emile Bottigelli, revista por Gerard Raulet. $\mathrm{p}$. 103-106 e, para as notas dos tradutores, p. 174-175.

5. MARX. Fondements de la critique de l'économie politique. Paris : Anthropos, 1967, trad. Roger Dangeville, p. 99. Corrigimos a tradução francesa, imprecisa, ao confrontá-la com o original alemão: Grundisse der Kritik der Politischen Ökonomie. Berlim: Dietz Verlag, 1953, p. 80.
EM TESE
BELO HORIZONTE
20
N. 1
JAN.-ABR. 2014
SAYRE; LÖWY; TEIXEIRA. Marx, Engels e os escritores românticos
P. $134-148$ 
em vários aspectos: num primeiro momento, ela retoma o argumento romântico acerca da "plenitude" do passado pré-capitalista e, num segundo instante, opõe simetricamente a ilusão romântica do retorno ao passado à apologia burguesa do presente. Por fim, considera legítima a crítica romântica ao mundo burguês, tomada como um contraponto negativo do mesmo e que deverá acompanhá-lo até o fim, ou seja, até o fim da sociedade burguesa. De acordo com os editores da Grundrisse, os românticos aos quais Marx se referiria nessa passagem são o economista conservador Adam Müller Thomas Carlyle, sobre quem nos deteremos mais adiante.

Seria falso limitar o interesse positivo demonstrado por Marx e Engels pelo Romantismo a seus anos de juventude, quando, sem dúvida, estiveram mais próximos dessa sensibilidade cultural (voltaremos a esse ponto). Afinal, os escritos tardios testemunham uma grande atenção ao trabalho de antropólogos e historiadores, de inspiração romântica, sobre as comunidades "primitivas": Maurer, Niebuhr, Morgan, Bachofen. A razão de tal interesse é claramente política, conforme o afirma Marx em uma carta a Engels de 25 março de 1858, no qual trata do historiador alemão Georg Ludwig Maurer - documento altamente significativo que deslinda, ao mesmo tempo, sua afinidade e sua distância para com o Romantismo: "A primeira reação contra a Revolução Francesa e a ideologia das Luzes a ela associada foi, naturalmente, a de tudo divisar sob o ângulo medieval, romântico, da qual mesmo nomes como Grimm não escaparam. A segunda reação - e ela corresponde à orientação socialista [...], consiste num mergulho para além da Idade Média, alcançando a época primitiva de cada povo. E as pessoas ainda se surpreendem ao encontrarem no mais antigo o mais moderno e ao descobrirem igualitários num tal grau que fariam tremer Proudhon". ${ }^{6} \mathrm{O}$ que Marx não parece levar em conta é que o Romantismo não necessariamente se vincula a esse "ângulo medievalizante": a referência a um passado "primitivo" igualitário é, também, uma das formas que pode tomar a crítica romântica à civilização, e isso já desde Rousseau e seu Discurso sobre as origens da desigualdade até alcançar os antropólogos por ele mencionados.

O escritor romântico, fascinado pela Idade Média, citado nessa carta é Jacob Grimm, que publicara, em colaboração com seu irmão Wilhelm, assim como com Von Arnim e com Brentano, a célebre coletânea de contos populares germânicos. Mas Grimm também fora filólogo e historiador do direito, e é provável que esse seja o contexto da segunda referência a ele, na mesma carta a Engels: "Além disso, mesmo Grimm, entre outros, tem em mente, graças a César, que os alemães se instalavam sempre a partir de comunidades familiares e não como indivíduos: 'gentibus cognationibusque que uno coiereant". ${ }^{7}$ Em outros termos: mesmo em Grimm,
6. MARX. Carta a Engels de 25 de março de 1858. In: MARX ENGLES. Ausgewählte Briefe. Berlim: Dietz Verlag, 1953, p. 231 (a tradução de Freville, op. cit, p. 126, é bastante falha). Marx não utiliza o termo Aufklärung (Luzes), mas Aufklärertum, uma expressão bastante pejorativa, que traduzimos por "ideologia das Luzes" (Fréville a traduziu como "progresso").

MARX. Ausgewählte Briefe. Berlim: Dietz Verlag, 1953, p. 234.
EM TESE
BELO HORIZONTE
v. 20
N. 1
JAN.-ABR. 2014
SAYRE; LÖWY; TEIXEIRA. Marx, Engels e os escritores românticos
P. $134-148$

Tradução e Edição 
8. MARX. Misère de la Philosophie. Paris: Ed. Sociales, 1947, p. 33.

9. MARX, ENGELS. Manifeste $d u$ parti communiste, p. 76. suposta encarnação das ilusões medievalistas românticas, descobre-se, assim como em Maurer, o interesse por formas comunitárias "primitivas" da Germânia antiga, tais quais Júlio César as havia descrito.

Em geral, encontramos nos escritos de Marx e Engels muitos temas inspirados na crítica romântica à civilização capitalista. É o caso, particularmente, da denúncia do caráter brutalmente quantificador do ethos burguês, a dissolução de todos os valores qualitativos - sociais, morais ou culturais - em favor de um único valor quantitativo, medido pelo dinheiro. Amplamente desenvolvida nos Manuscritos de 1844 essa problemática também pode ser encontrada numa surpreendente passagem de Miséria da Filosofia (1847): "Este é o tempo em que as coisas que antes eram [...] ofertadas, mas jamais vendidas, adquiridas, porém nunca compradas - virtude, amor, opinião, ciência, consciência, etc -, em que tudo, enfim, se transforma em comércio. Este é o tempo da corrupção geral, da venalidade universal [...]”. ${ }^{8} \mathrm{Ou}$, ainda as famosas linhas do Manifesto Comunista, denunciando uma sociedade invadida pelas "águas geladas do cálculo egoísta", na qual o único laço subsistente entre os seres humanos é o "pagamento em espécie", o cash nexus; em suma, uma sociedade cuja classe dominante, a burguesia, "dissolveu dignidade pessoal no valor de troca"..$^{9}$ O que caracteriza tais críticas como românticas é a comparação - implícita ou explícita
- com um passado pré-capitalista, onde tal corrupção das relações sociais ainda não tinha lugar.

É claro que alguns temas de extração românticos frequentemente retornam nos escritos de Marx e Engels, tanto em sua juventude quanto na "maturidade". Em particular: 1) a degradação do trabalho humano pelos malefícios do maquinismo e da divisão do trabalho, 2) a perda, no processo civilizatório, das qualidades humanas características das comunidades ditas "primitivas", desde as sociedades gentílicas do passado até as tribos indígenas ou as comunidades rurais russas, entendidas como sociedades livres, igualitárias e comunitaristas. Se esses elementos temáticos não são mais do que uma faceta do pensamento dos fundadores do marxismo e se não se instituem como uma perspectiva global, não é menos verdadeiro que essa dimensão romântica é tão crucial quanto desconhecida.

\section{MARX E ENGELS: SOBRE OS ESCRITORES}

\section{ROMÂNTICOS}

Contrariamente a uma imagem largamente difundida, para Marx e Engels a literatura de imaginação sempre teve importância fundamental. Em sua juventude, Marx compôs algumas peças literárias - principalmente poemas - e chegou mesmo a sonhar com a vida de escritor. Depois disso, e ao longo de toda a sua colaboração com Engels, ambos se mostraram fortemente interessados em literatura, tanto 
10. A extensão da cultura literária de Marx e sua presença na obra são magistralmente analisadas em PRAWER. Karl Marx and World Literature. Oxford: Oxford U P. 1976.

11. Conforme o observa Terry Eagleton em prefácio à tradução inglesa, uma das principais contribuições do estudo de Mikhail Lifshitz, La philosophie de l'art de Karl Marx (edição russa de 1933) é a de "analisar os julgamentos estéticos de Marx como um elemento interno ao seu desenvolvimento teórico geral", além de mostrar como em Marx, "é forte e contínuo o diálogo com os produtos de imaginação". LIFSHITZ. The Philosophy of Art of Karl Marx. Trad. R. B. Winn. Londres: Pluto P, 1973, p. 7. a clássica quanto a moderna, continuamente imersos nesse tipo de leitura e sempre incluindo em seus escritos - inclusive suas correspondências - referências literárias. ${ }^{10}$ Além disso, longe de ser um mero passatempo, esse interesse por obras estéticas, ao implicar uma certa maneira de se conceber a arte, está integralmente associado ao conjunto de seus trabalhos. ${ }^{11}$ Não obstante a importância da literatura e da arte para os fundadores do marxismo, são relativamente poucos os textos nos quais desenvolvem, com algum detalhe, suas ideias acerca dos movimentos, autores e obras. Em muitos casos, deixaram apenas observações fragmentárias, o mais das vezes misturadas a comentários sobre temas políticos, históricos, entre outros. Mas a abordagem das relações de Marx e Engels com obras literárias pode contar com outra fonte de informações, bastante rica: o testemunho de pessoas de seu círculo íntimo e familiar. Tal como ocorre com todas as memórias pessoais - frequentemente narradas muito depois dos fatos ocorridos e, por vezes, pouco fiáveis -, esse recurso pede cautela. Dito isto, através do cotejo entre diferentes textos e testemunhos, torna-se possível identificar, com bastante segurança, um certo número de pontos de vista ou, em outros casos, constituir hipóteses plausíveis.

Como já dissemos antes, em nossa investigação sobre a abordagem de Marx e Engels relativa a escritores e obras românticas, não nos limitamos apenas aos que assim foram designados. No caso de alguns autores "realistas" - como Balzac e Dickens - não é certo que nossos autores os teriam classificado como românticos. Ainda assim, tampouco é menos verdadeiro que os comentários acerca desses dois romancistas encaixam-se bem na concepção de Romantismo indicada acima - concepção essa não muito distante da que o próprio Marx sugere nos Grundrisse. Quanto às noções que lhes foram próprias, de início, referiam-se, sobretudo, à "escola romântica” da época. Como afirma Stefan Morawski, "Marx e Engels foram, ambos, e de forma independente, partidários desse movimento, o qual, sob a influência de Hegel, passarão a rejeitar [...]. No contexto das correntes intelectuais da primeira metade da década de 1840, eles se situavam, sem dúvida, como antirromânticos. No entanto, em um sentido mais amplo, Marx e Engels beberam no Romantismo..." ${ }^{12} \mathrm{Na}$ sequência, se continuaram a parecer, no geral, hostis a essa escola e sua ideologia, tal como a entendiam, e se Marx, em diversas ocasiões, fustigou os românticos franceses Chateaubriand e Lamartine, ${ }^{13}$ ele e Engels manifestaram sua admiração por um grande números de escritores que participariam da tendência romântica, tal como a definimos. No restante deste texto, abordaremos alguns de seus autores principais, após tratar das leituras, gostos e produções românticas de Marx em sua juventude e em sua vida e meio familiar mais tardios.
12. MORAWSKI. Marx and Enge/s on Literature and Art. Introduction, p. 44.

13. No caso de Lamartine, os ataques de Marx voltam-se exclusivamente para o seu papel político. Sobre a atitude de Marx relativa aos dois autores, ver PRAWER. Karl Marx and World Literature, p. 162-64, 165, 169, 205-06, 257, 271, 420

EM TESE BELO HORIZONTE $\quad$ v. $20 \quad$ N. $1 \quad$ JAN.ABB. $2014 \quad$ SAYRE; LÖWY; TEIXEIRA. Marx, Engels e os escritores românticos $\quad$ P. 134-148


14. Ver ibid, p. 9

15. Ver BLUMERBER, Werner. Portrait of Marx, trad. D. Scott. New York: Herder and Herder

1962) p. 22 .

16. LIFSHITZ. The Philosophy of Art of Karl Marx, p. 16.

\section{A ÉPOCA DE JUVENTUDE DE MARX}

Durante seus estudos universitários (1835-1841), inicialmente em Bonn e, depois, em Berlim, Marx esteve próximo das correntes românticas alemãs e chegou a escrever obras literárias de tipo romântico, para, em seguida, tornar-se cada vez mais crítico em relação a tal corrente e às suas próprias criações no gênero. Em 1835, em Bonn, Marx frequentou os cursos de A. W. Schlegel, um dos fundadores do movimento alemão, enquanto, em Berlim, conheceu pessoalmente Bettina von Arnim, membro proeminente do círculo romântico da época. ${ }^{14}$ Os diversos poemas, o primeiro ato de um drama, assim como os primeiros capítulos de um romance satírico escrito por Marx na fase inicial de seus estudos encerram evidentes características românticas. Seu esboço romanesco adota a veia fantástica e cômica de um E. T. A Hoffmann, e os poemas não apenas recuperam um conjunto de imagens típicas da escola romântica alemã - harpas e barcos encantados, cantos de sereias, delírios noturnos, etc. ${ }^{15}$ - mas também certos temas essências ao Romantismo: a desumanização experimentada pelo poeta na cidade moderna, a falta de grandeza da realidade presente, a nostalgia de um verdadeiro lar (Sehnsucht). Num desses poemas, o mundo burguês atual é comparado a um "teatro de macacos" que evacua emoções e fantasias, reduzindo a existência a "fórmulas matemáticas" e puramente corporais. ${ }^{16}$

EM TESE
Nesses primeiros escritos, o único remédio para os males do presente é permanecer afastado, refugiando-se no universo poético, e é essa recusa em se envolver com o mundo, tomada como uma característica definidora da escola romântica, que Marx acabará por rejeitar. Mas isso não significa que ele renegue, necessariamente, todos os elementos da visão romântica que, antes, o haviam atraído. A persistência de aspectos do Romantismo é, aliás, sugerida na famosa carta que Marx escreveu a seu pai em 1837, na qual anuncia o advento de um novo ponto de vista, mais imerso no real e já manifesto em poemas recentes: “... esses últimos poemas são os únicos que me fizeram entrever, de repente, e como por efeito de uma varinha de condão [...], o reino, semelhante a um longínquo palácio feérico, da poesia verdadeira, face ao qual todas as minhas criações viraram pó." ${ }^{17} \mathrm{O}$ jovem Marx descreve, aqui, através de metáforas fantásticas - a "varinha de condão" e o "palácio feérico" - seu retorno à realidade. De fato, mesmo em sua "maturidade", ele não perderá o gosto pelo fantástico - livre jogo da imaginação - bem como por alguns escritores românticos que o cultivavam.

\section{MARX EM FAMÍLIA}

É na intimidade do círculo familiar (que incluía muitos amigos, dos quais Engels é o principal) que essa continuidade melhor se deixa ver. Pois se, a partir da década de 1840 , Marx não persistiu na escrita de obras literárias, segundo
17. MARX, ENGELS. Sur la littérature et l'art. p. 113.

Tradução e Edição 
diversos testemunhos ele continua a exercitar, oralmente, sua imaginação - de forte matiz romântico - em contos que inventava para suas filhas. De acordo com Paul Lafargue, futuro marido de Laura, uma das filhas de Marx, "quando [elas] eram pequenas, ele costumava distraí-las durante os passeios narrando-lhes intermináveis contos de fadas, contos que inventava no percurso e que prolongava em função de sua extensão..." Já Eleanor, caçula das filhas, dá mais detalhes sobre um desses contos em particular: "Para mim, de todas essas incontáveis e maravilhosas histórias, a preferida era a de Hans Rockle. Ela durava meses e meses e se compunha de um conjunto de narrativas [...] Hans Rockle era um mágico à moda de Hoffmann, dono de uma loja de brinquedos e sem um centavo no bolso. Sua loja abrigava os objetos mais extraordinários: homens e mulheres feitos de madeira gigantes e anões, reis e rainhas , mestres e aprendizes [...] Embora fosse um mágico, Hans nunca conseguia pagar as suas dívidas [...]; assim, foi contra sua vontade que vendeu todas as suas belas coisas para o diabo". ${ }^{18}$

A inspiração que Marx encontrava em E. T. A. Hoffmann é atestada também por outras fontes. No final da década de 1860, enviou uma cópia de um dos contos do mesmo "Pequeno Zaches" (Klein Zaches genannt Zinnober) - não só a amigos da família (os Kugelmann), mas também a Engels. Ora, como acertadamente observou S. S. Prawer: "a literatura mundial não oferece símbolo mais justo da alienação do que esse conto, narrando a história de um anão deformado a quem, graças a um poderoso feitiço, se atribui tudo o que outros fizeram e disseram de bom e louvável". ${ }^{19}$

Marx era, portanto, um apreciador do fantástico romântico de Hoffmann. Ainda segundo Paul Lafargue, ele também apreciava muitíssimo a poesia do romântico escocês Robert Burns - poesia embebida nas lendas e folclores do país -, cujos versos gostava de ouvir declamados por suas filhas. ${ }^{20}$ De modo geral, era costume da família ler em voz alta e discutir obras literárias. Nessas conversas e leituras familiares, um lugar especial era reservado a certos autores românticos que, doravante, examinaremos de modo mais detido, a partir de escritos e testemunhos pessoais de Marx e Engels.

\section{THOMAS CARLYLE}

Ensaísta político, correspondente de Goethe, a meio caminho entre a filosofia e a literatura, Thomas Carlyle é um dos escritores românticos mais apreciados por Marx e Engels. É de seu ensaio sobre o Cartismo (1843), cuidadosamente lido anotado por Marx em 1845 e amplamente citado no livro de Engels sobre a situação da classe trabalhadora na Inglaterra (1845), que eles irão extrair a crítica ao "cash nexus", desenvolvida em Manifesto do partido comunista. Se não mencionam o autor no texto de 1848, Marx o cita em parágrafo de
19. PRAWER. Karl Marx and World Literature, p. 373.

20. MARX, ENGELS. Sur la littérature et l'art, p. 176. 
21. ENGELS. "Die Lage Englands" 1844. In: MARX, ENGELS. Werke, Berlim : Dietz Verlag, 1961, vol. 1, p. 538;542. O partido tory reunia whig federava os liberais o whig federavi

22. ENGELS. "Thomas Carlyle", 1850. In: ibid, vol. 7, p. 255. (grifo nosso) um ensaio, publicado em Grundrisse. Quanto a Engels, publica, em 1844, uma calorosa resenha sobre Past and Present (1843), de Carlyle, do qual cita, com aprovação, as virulentas filípicas contra o "Mamonismo", a religião do deus do dinheiro. Claro que reconhece ser "Thomas Carlyle [...] originalmente um Tory”, mas essa opção conservadora não deixa de ter laços com as qualidades de seu livro: "É certo que um Whig jamais poderia escrever um livro que foi, em parte, tão humano quanto Past and Present". ${ }^{21}$ Alguns anos mais tarde, Engels volta à carga, em artigo sobre Carlyle, publicado em 1850. Embora criticando severamente a virada reacionária desse autor após a revolução de 1848, ele mantém sua estima por seus ensaios anteriores: "Thomas Carlyle tem o mérito de ter se posicionado, em seus escritos, contra a burguesia, numa época na qual as concepções, gostos e ideias burgueses dominavam por completo a literatura inglesa oficial, e isso de maneira por vezes propriamente revolucionária. [...] Mas, em todos os seus escritos, a crítica ao presente está estreitamente associada a uma extraordinariamente pouco histórica apoteose da Idade Média, muito frequente, ademais, entre os revolucionários ingleses, como, por exemplo, Cobbett e uma parte dos cartistas". ${ }^{22}$ Essa passagem é fundamental para que se compreenda o entendimento eminentemente dialético de Engels acerca do Romantismo. De um lado, ele percebe que crítica romântica do presente está "estreitamente associada" à nostalgia - e, o mais das vezes, à idealização - do passado; de outro, reconhece que, em certos casos, essa crítica pode adquirir uma dimensão verdadeiramente revolucionária.

\section{BALZAC}

Assim como para muitos críticos literários clássicos, para Jean Fréville, Balzac não é romântico já que é um realista. Ora, existem diversos autores marxistas - dentre os quais J. O. Fischer, Pierre Barbéris e, em alguns escritos, Georg Lukács - que dão conta com perfeição do fato de que o autor d'A Comédia Humana foi, ao mesmo tempo, romântico e realista. Se o Romantismo é, como Marx reconheceu nos Grundrisse, a crítica à sociedade burguesa em nome de uma plenitude passado, Balzac é, evidentemente, um romântico.

Marx nutria verdadeira veneração por Balzac. O Capital está repleto de referências às intuições profundas desse romancista, assim como sua correspondência com Engels. Sobre o tema, dispomos de um testemunho revelador de Paul Lafargue: "Seus romancistas preferidos foram Cervantes e Balzac. [...] Ele tinha uma tal admiração por Balzac que se propôs a escrever um livro de crítica sobre a Comédia Humana tão logo terminasse sua obra econômica." ${ }^{23}$ Paixão compartilhada por Engels, o qual, numa famosa carta à escritora inglesa Margaret Harkness, de abril de 1888, propõe a seguinte análise: "Balzac, que acredito ser um mestre do realismo infinitamente superior a todo e qualquer Zola, do passado, do
23. LAFARGUE, Paul. "Les goûts littéraires de MarX. In : MARX, ENGELS. Sur la littérature et l'art. p. 177.
EM TESE
20

N. 1

JAN.-ABR. 2014 
presente ou do futuro, oferece-nos, em sua Comédia Humana, a mais maravilhosamente realista história da sociedade francesa, descrevendo [...] a pressão cada vez maior que a burguesia ascendente exerceu sobre a nobreza restaurada em 1815 [...]. Ele descreve como os últimos resquícios dessa sociedade, a seu ver, exemplar, sucumbiram, pouco a pouco, diante da intrusão do parvenu vulgar da finança, ou foram por ele corrompidos [...]. Aprendi mais [com Balzac], mesmo no tocante a detalhes econômicos (por exemplo, a redistribuição da propriedade real e pessoal após a revolução), do que em todos os livros de historiadores, economistas e estatísticos profissionais da época, tomados em conjunto. Sem dúvida, em política, Balzac foi um legitimista; sua grande obra é uma perpétua elegia a deplorar a irremediável decomposição da alta sociedade; suas simpatias se dirigem para o lado da classe condenada a morrer. Mas, apesar disso, sua sátira nunca é mais mordaz e sua ironia mais amarga do que quando põe em cena esses aristocratas [...].”. Engels atribui tal lucidez de Balzac ao que chama de "triunfo do realismo" sobre seus "preconceitos políticos", mas podemos também nos perguntar se, como ocorre com Carlyle, tal lucidez não estaria "estreitamente associada" a essa nostalgia do passado. Sua ironia amarga no que toca à aristocracia de sua época não seria, assim, inspirada exatamente pela evidência de sua corrupção pelo dinheiro burguês? ${ }^{24}$.

\section{CHARLES DICKENS}

Marx também admirava os escritores realistas ingleses, dentre os quais alguns poderiam ser classificados, assim como Balzac, como românticos. Em um artigo sobre a burguesia inglesa, datado de agosto de 1854, escreveu:

A brilhante escola moderna de romancistas ingleses, cujas páginas eloquentes revelaram ao mundo mais verdades do que todos os políticos profissionais, polemistas e moralistas em conjunto, descrevendo todas as camadas da classe média, do rentista "altamente respeitável", detentor dos valores de Estado e que olha com desprezo para os negócios, até o pequeno comerciante e o escrevente. E como Dickens e Thackeray, a Srta Brontë e a Sra. Gaskell os retrataram? Repletos de vaidade, afetação, tirania mesquinha e de ignorância; o mundo civilizado confirmou esse julgamento através de um epigrama que os flagela e persegue e que afirma 'se tratar de uma classe subserviente diante dos superiores e tirânica com os inferiores. ${ }^{25}$

Essa passagem - cujo argumento seria retomado por Engels em formulação similar sobre Balzac, citado anteriormente neste texto ${ }^{26}$ - revela a grande fonte de conhecimento que fora, para Marx, um certo tipo de literatura realista, cuja crítica, ao mesmo tempo social e moral e, muitas vezes, de inspiração romântica, é lúcida e impiedosa . O termo inglês "middle class" significa mais "burguesia" do que "classe
25. MARX. La classe moyenne anglaise. New York Tribune, 1 de agosto de 1954. In : ibid, p. 134.

26. S.S. Prawer indica (op. Cit, $\mathrm{p}$ 237) que, segundo os editores das e Engels (MEW), o artigo que acabamos de citar teria sido pelos radetores modificado pelos redatores do Jornal em questáo. Porem, a similaridade de formulaçao entre nossa citaçâa e a que a precede, assinad por Engels, poderia ser um indicio, entre outros, de que o texto final do artigo não altera substancialmente o pensamento de Marx (e de Engels).

\begin{tabular}{|c|c|c|c|c|}
\hline EM & BELO HORIZONTE & 0 & . & JAN.-ABBR 2 \\
\hline
\end{tabular}


27. MARX. Das Kapital, vol. 4, p. 465, citado em MARX, ENGELS. Verlag Bruno Henschel und Sohn: 1948 , p. 59. média”. Sem ser um legitimista, como Balzac, Dickens não deixava de ser um escritor romântico, profundamente influenciado por Carlyle, de quem retoma numerosos temas - notadamente a crítica ao maquinismo e à quantificação mercantil. A que obras de Dickens Marx se refere aqui? Ele conhecia bem Oliver Twist, cujo primeiro capítulo oferece uma inesquecível imagem do sofrimento das crianças pobres internadas em orfanatos e vítimas da cruel "filantropia" burguesa. Marx cita uma passagem em O Capital, sobre o uso capitalista das máquinas, mas se trata de uma frase do bandido Bill Sikes, relativa à impossibilidade de se criticar o uso da faca para a degola das vítimas sem a abolição desse instrumento precioso e, consequentemente, o retorno à barbárie. ${ }^{27} \mathrm{O}$ mais provável é que a frase do artigo de 1854 remeta a Hard Times, que acabara de ser publicada em folhetim (a partir de abril 1854) e que denunciava, com uma ironia feroz, a "tirania mesquinha" dos burgueses, seu espírito frio e quantificador, seu utilitarismo medíocre e as nefastas consequências do maquinismo industrial.

\section{AS IRMÃS BRONTË}

$\mathrm{Na}$ lista de romancistas ingleses acima mencionada, também encontramos a "Senhorita Brontë". Não está claro qua das três irmãs - Emily, Charlotte e Anne - todas elas romancistas, é visada aqui. Um testemunho oriundo do meio familiar atesta que ao menos as duas primeiras eram conhecidas e admiradas pela família Marx. A escritora Marian Comyn, amiga de infância de Eleanor Marx, lembra ter ficado impressionada com o número de obras literárias inglesas da biblioteca do pai da amiga, mas narra, com mais detalhes, "uma conversa na hora do almoço sobre autores vitorianos e a admiração expressa por toda a família por Charlotte e Emily Brontë, ambos consideradas muito superiores a George Eliot”. ${ }^{28}$

A alusão de Marx no artigo de jornal de 1854 pode se referir ao único - não obstante imponente - romance de Emily Brontë, Wuthering Heights (O morro dos ventos uivantes), publicado em 1847. Essa obra, que retrata uma paixão amorosa atormentada, associada à natureza selvagem do extremo norte da Inglaterra e ao seu folclore "primitivo", também coloca em cena, numa representação ao mesmo tempo sutil e violenta, a desumanização e a reificação dos laços humanos partir das modernas relações de classe. ${ }^{29}$ Contudo, conforme observado por S. S. Prawer, não encontramos nenhuma referência explícita a Emily Brontë ou ao seu romance na obra escrita de Marx. ${ }^{30}$ Prawer assinala, porém, uma significativa alusão a Charlotte, numa carta de Marx à sua filha, Jenny, datada de 1869, por ocasião de uma visita a Yorkshire, região onde as irmãs Brontë viveram. Em um trecho, descreve uma paisagem composta "de belas árvores e [de] um grupo de montanhas em forma de anfiteatro, cada uma mais alta do
28. COMYN, Marian. “My Recollections of Karl Marx", The Nineteenth Century and After, vol. 91, janeiro de 1922. Esse texto se encontra disponível em: http://www.marxist.org/subject/ women/authors/comyn/marx. htm. Ver p. 6-7.

29. Para uma excelente análise marxista desse romance, ver o EAGLETON Myths of Power: A Marxist Study of the Brontës. Londres: Macmillan, 1975.

30. PRAWER. Karl Marx and World Literature, p. 396.
EM TESE
BELO HORIZONTE
v. 20
N. 1
JAN.-ABR. 2014
SAYRE; LÖWY; TEIXEIRA. Marx, Engels e os escritores românticos
P. $134-148$

Tradução e Edição 
31. Ibid, p. 377.

32. Para uma análise do conflito de classes em Shirley, ver Patricia Oxford U P, 2006, p. 110-121.

Oxford UP, 2006, p. 110-121.

33. ENGELS. La situation de la classe laborieuse en Angleterre. CFuvres, t. IV ; citado em MARX, ENGELS. Sur la littérature et l'art, p. 159-60. que a outra e todas envoltas no véu azul que sempre encantou tanto Currer Bell [pseudônimo de Charlotte Brontë]". ${ }^{3}$ Embora não tenha sido nomeado, o romance em que aparece esse encantador "véu azul" não é Jane Eyre, mas Shirley (1849) Ora, esse "romance industrial" encena o conflito de classe a opor operários têxteis, desempregados após a introdução de novas máquinas, e o patrão, arrogante, tirânico e insensíve a tudo, afora aos lucros de sua usina. Como ocorre em outros textos românticos do mesmo tipo, é através da ação de uma mulher que esse último será levado a uma tomada (parcial) de consciência de seus erros. Não é impossível, portanto, que Marx pensasse muito particularmente em Shirley ao incluir a "Senhorita Brontë" em sua lista acerca da "brilhante escola" inglesa. ${ }^{32}$

\section{SHELLEY E BYRON}

A natureza tendenciosa e falaz da apresentação de Fréville sobre as ideias de Marx e Engels se exibe no fato de ter incluído, na seção "para uma literatura revolucionária", um comentário muito elogioso de Engels acerca de dois poetas ultrarromânticos: "Shelley, o brilhante e profético Shelley, e Byron, em seu ardor sensual e sua amarga sátira à sociedade existente, são lidos, o mais das vezes, pelos operários os burgueses só possuem edições censuradas, family editions, arrumadas ao gosto da moral hipócrita do dia." ${ }^{33}$ Com efeito, teria sido difícil colocar uma citação como essa na seção intitulada "contra o Romantismo"!

A única outra menção a Shelley e Byron presente na coletânea de Fréville diz respeito a um distinguo relativo aos dois poetas, supostamente feito por Marx, mas repertoriado apenas através de terceiros. Trata-se de uma passagem do panfleto "Shelley socialista", publicado em 1888 por Edward Aveling, em colaboração com Eleanor Marx, sua infeliz companheira ${ }^{34}$ : "Marx [...] adorava repetir que 'a verdadeira diferença entre Byron e Shelley está no seguinte: todos os que o amam e o compreendem consideram uma felicidade o fato de Byron ter morrido aos trinta e seis anos, pois teria se tornado um burguês reacionário caso tivesse vivido mais tempo; por outro lado, eles lamentam a morte de Shelley aos vinte e nove anos, pois se tratava de um completo revolucionário, que teria sempre pertencido à vanguarda do socialismo". ${ }^{35}$ Para S. S. Prawer, porém, tal afirmação é um caso claro de testemunho não confiável. Pois, como ele insiste, quando Marx refere-se a Byron em seus escritos, é sempre em tom "de aprovação evidente. [...] O que sabemos sobre a sensibilidade literária e discernimento político de Marx não sugere que ele pudesse ser suficientemente obtuso a ponto de ver um 'reacionário burguês' potencial no autor de Don Juan. Por outro lado, conhecemos muito sobre a 'propensão para falsificar fatos' de Edward Aveling”. ${ }^{36}$ Ao contrário de
34. A história dessa relação é bem conhecida: vivendo em concubinato com Eleanor Marx durante anos, Aveling manteve múltiplas outras ligações amorosas e terminou por trocar a companheira por uma jovem atriz; porém, vítima de uma grave doença, voltou para Eleanor para se tratar; parcialmente curado, confiou-lhe ter se casado secretamente com a atriz e sua intenção de voltar para ela. Se tal comportamento sem dúvida não foi a única causa do suicídio de Eleanor Marx, ocorrido um pouco depois, não há grandes dúvidas de que contribuiu para isso.

35. MARX, ENGELS. Sur la littérature et l'art, p. 180

36. PRAWER. Karl Marx and World Literature, p. 397. A frase citada é de Yvonne Kapp, biógrafa de Eleanor Marx.

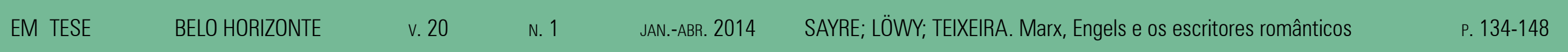


Fréville, que adora distribuir mais ou menos pontos em função da ideologia, Prawer reconhece em Marx a capacidade de ir além desse tipo de juízo, o que teria lhe possibilitado tantas vezes reconhecer qualidades em autores românticos pouco conformes à sua própria perspectiva. Parece-nos provável, portanto, que Marx, assim como Engels, apreciasse, sem distinções, o aporte literário de ambos os escritores.

\section{WALTER SCOTT}

É também em testemunhos pessoais - mas que são, nesse caso, bem mais confiáveis - que descobrimos a grande estima de Marx pelo romancista histórico Walter Scott. Pau Lafargue, que durante anos esteve com ele quotidianamente, conversando sobre os temas mais diversos, afirma, em suas Memórias, que Marx "assim como Darwin, era um grande leitor de romances. [...] Os escritores modernos que mais o atraíram foram Paul de Kock, Charles Lever, Alexandre Dumas e Walter Scott. Ele considerava Old Mortality, do último, uma obra magistral”. Além disso, nas memórias de infância de Eleanor Marx, já mencionadas, ela atesta que, dentre as leituras favoritas que Marx fazia às filhas, figurava Scott. Ela fala da "exaltação por Walter Scott" que compartilhava com o pai durante essas leituras e indica, de form mais ampla: "Devo acrescentar que Marx relia sem cessar Walter Scott; ele o admirava e conhecia quase tão bem quanto Balzac ou Fielding". ${ }^{37}$
Pode-se perguntar o que mais atraiu e fascinou Marx na obra desse escocês, conservador tory, apaixonado pelo pas sado de seu país e, em especial, pelas comunidades primitivas dos clãs das regiões mais recuadas e selvagens. Talvez o que mais apreciasse, assim como Lukács em $O$ romance histórico, fosse a representação extraordinariamente vívida - e, à época, nova - do próprio processo histórico. Porém, com base no que sabemos sobre o interesse de Marx e de Engels por sociedades gentílicas pré-capitalistas e pelos estudos antropológicos acercas de tais sociedades, parece-nos plausível que uma parte dessa atração venha das descrições de tais sociedades e dos valores que poderiam encarnar. Atração, pois, cujas raízes estariam na dimensão romântica da sensibilidade de Marx. ${ }^{38}$

Em conclusão, é claro que Marx e Engels, apesar da antipatia por alguns escritores românticos, estavam longe de uma rejeição integral da visada romântica e, ao contrário, nela se inspiravam em seu apreço às importantes contribuições de certos escritores de peso. Quanto à atração que sentiam por certas facetas da literatura romântica mais características como o fantástico e o onírico, o sentimento da natureza ou a valorização das grandezas do passado - ela existe, mas deve ser lida em filigrana, através das lembranças dos que lhes eram próximos. Em seus escritos de "maturidade", os elogios de Marx e Engels vão mais para obras realistas, cujas críticas ferozes à civilização burguesa, de inspiração romântica,
37. MARX, ENGLES. Sur la littérature et l'art, p. 177, 182-83.
EM TESE
38. É importante notar que em $O$ Romance histórico, Lukács, empregando uma definição mais limitada do termo e redigindo sua obra num momento antirromântico, não considera Walter Scott como um escritor romântico. Ver o primeiro capítulo de Le Roman Historique. Paris: Payot, 1965 
39. Com o objetivo de facilitar as discussoes sobre o assunto aqu tratado, os editores tomaram referências bibliográficas as tradução. Todas seguem fieis às traduça. Todas seguem fieis às notas do. rexto originl, publicado na revista Em lhes parece repleta de ensinamentos. Com esses romances, eles aprenderam mais, segundo seus testemunhos, do que em todos os escritos de historiadores, economistas, estatísticos, políticos e polemistas contemporâneos, tomados em conjunto: o que não é pouco! É necessário, então, considerar tais escritores como uma das fontes maiores dessa obra ou, se quiser, como matérias a partir das quais eles construíram um diagnóstico próprio acerca da facies hippocratica do mundo capitalista.

\section{REFERÊNCIAS ${ }^{39}$}

BLUMERBER, Werner. Portrait of Marx. Trad.: D. Scott. New York: Herder and Herder, 1972

COMYN, Marian. "My Recollections of Karl Marx", The Nineteenth Century and After, vol. 91, janeiro de 1922, p. 6-7 Disponivel em: http://www.marxist.org/subject/women/authors/ comyn/marx.htm

EAGLETON, Terry. Myths of Power: A Marxist Study of the Brontës. Londres: Macmillan, 1975.

ENGELS, Friedrich. "Lettre à Miss Harkness", abril de 1888. In MARX, ENGELS. Sur la littérature et l'art. FRÉVILLE, Jean (org) Paris: ESI, 1936, p. 148-49.

ENGELS, Friedrich. "Die Lage Englands" 1844. In: MARX, Karl. ENGELS, Friedrich. Werke, Berlim: Dietz Verlag, 1961, vol. 1, p. 538-542.
ENGELS, Friedrich. "Thomas Carlyle", 1850. In: MARX, Karl. ENGELS, Friedrich. Werke, Berlim: Dietz Verlag, 1961, vol. 7, p. 255- 265.

NGHAM, Patricia. The Brontës Oxford: Oxford U P, 2006, p. 110 121

LAFARGUE, Paul. "Les goûts littéraires de Marx". In : MARX ENGELS. Sur la littérature et l'art. FREVILLE, Jean (org). Paris: ESI, 1936, p. 177-189.

LIFSHITZ, Mikhail. The Philosophy of Art of Karl Marx. Trad: R B. Winn. Londres: Pluto P, 1973.

LÖWY, Michael. SAYRE, Robert. Révolte et mélancolie: le romantisme à contre-courant de la modernité. Paris : Payot, 1992

LÖWY, Michael. Le romantisme révolutionnaire. Europe, número 900 - Avril 2004

LUKÁCS, Geörgy. Le Roman Historique. Paris: Payot, 1965.

MARX, Karl. La classe moyenne anglaise. New York Tribune, 1 de agosto de 1954. In : MARX, ENGELS. Sur la littérature et l'art. FREVILLE, Jean (org). Paris: ESI, 1936, p. 134.

MARX, Karl. ENGLES, Friedrich. Sur la littérature et l'art FRÉVILLE, Jean (org). Paris: ESI, 1936.

MARX, Karl. Misère de la Philosophie. Paris: Ed. Sociales, 1947.
EM TESE

BELO HORIZONTE

v. 20

N. 1

JAN.-ABR. 2014

SAYRE; LÖWY; TEIXEIRA. Marx, Engels e os escritores românticos

P. $134-148$ 
MARX, Karl. ENGELS, Friedrich. Über Kunst und Literatur.

Berlim: Verlag Bruno Henschel und Sohn, 1948.

MARX, Karl. Lettre à Engesl du 25 mars 1858. In: MARX Karl ENGLES, Friedrich. Ausgewählte Briefe. Berlim: Dietz Verlag, 1953

MARX, Karl. Fondements de la critique de l'économie politique Trad.: Roger Dangeville. Paris: Anthropos, 1967.

MARX, Karl. ENGELS, Friedrich. Manifeste du parti communiste Trad.: Emile Bottigelli, revista por Gerard Raulet. Paris: Flammarion, 1998.

MORAWSKI, Stefan. Introduction. In: BAXANDALL, Lee.

MORAWSKI, Stefan (orgs). Marx and Engels on Literature and Art. St. Louis: Telos Pr, 1973.

PRAWER. Karl Marx and World Literature. Oxford: Oxford U P. 1976 